\title{
Factors controlling chorioallantoic placentation in the mare
}

\author{
Francesca Stewart ${ }^{1,2}$, Cornelia Gerstenberg ${ }^{1}$ and W.R. Allen ${ }^{1}$ \\ 1 University of Cambridge, Department of Clinical Veterinary Medicine, Newmarket \\ 2 The Babraham institute, Babraham, Cambridge
}

\begin{abstract}
Summary
Previous studies have indicated significant involvement of both fetal and maternal growth factors during development of the non-invasive chorioallantoic placenta in the mare. This study has utilised a model of equine placental failure, created by transferring donkey conceptuses to horse mares, to further investigate the potential role of two maternal growth factors, transforming growth factor $\beta 1$ (TGF $\beta 1$ ) and epidermal growth factor (EGF). Growth factor expression levels and cellular proliferation rates were analysed using in situ hybridisation and immunohistochemical techniques in placental biopsies taken from three mares carrying healthy horse conceptuses and three mares carrying transferred donkey conceptuses in the process of dying. The expression levels of EGF and TGF $\beta 1$ in the endometrium and the cellular proliferation rates within the allantochorion were greatly perturbed in the placentas of the mares carrying failing donkey conceptuses. TGF $\beta 1$ expression was higher than normal, whereas EGF expression and cell proliferation rates were much reduced, particularly in the regions of the uterus showing poor placentation and infiltration of the endometrium by maternal lymphocytes. The results suggest that increased levels of TGF $\beta 1$ in the endometrium may be responsible for reduced EGF expression in the endometrial glands. This, in turn, could be responsible for the impaired proliferation of the allantochorion seen in the failing pregnancies. The evidence gives further support to the concept that growth factors play a significant role in development of the equine placenta. The results also have significance in relation to pregnant mares with chronic endometrosis where reduced or absent EGF has been observed in fibrotic glands "nests", a characteristic feature of endometrosis.
\end{abstract}

Keywords: $\quad$ horse, placenta, growth factors, cell proliferation

\section{Regulationsmechanismen bei der Plazentation der Stute}

In früheren Studien wurde darauf hingewiesen, daß sowohl fetale als auch maternale Wachstumsfaktoren einen bedeutenden Einfluß während der Entwicklung der „nicht-invasiven“ epitheliochorialen Plazenta der Stute haben. In dieser Arbeit wurde zur näheren Untersuchung der potentiellen Rolle zweier maternaler Wachstumsfaktoren (transforming growth factor - TGF $\beta 1$ - und epidermal growth factor EGF) das "Esel-in Pferd" -"donkey in the horse-“ Modell eingesetzt. Ein Modell, in dem ein Eselkonzeptus in einen Stutenuterus verbracht wird, und somit das Versagen der equinen Plazentation vorprogrammiert ist.

Zur Verfügung standen Plazentabiopsien von drei mit gesunden Pferdefeten tragenden Stuten sowie von drei Stuten, die einen im Absterben befindlichen Eselfetus trugen. Die Expression der Wachstumsfaktoren und die zelluläre Proliferationsrate wurde mittels in-situ-Hybridisierung und Immunhistologie ermittelt.

In den Plazenten der Stuten, die einen Eselfetus trugen, zeigte das Expressionsmuster von EGF und TGF $\beta 1$ im Endometrium und die zelluläre Proliferationsrate im Allantochorion ein verwirrendes Bild. Die TGF $\beta 1$-Expression war höher als normal, während die EGF-Expression sowie die Zellproliferation stark reduziert war, insbesondere in den Regionen des Uterus, die eine geringe Plazentation und eine Infiltration des Endometriums mit maternalen Lymphozyten zeigten.

Aufgrund dieser Resultate wird vermutet, daß erhöhte TGF $\beta 1$-Werte im Endometrium verantwortlich sind für eine Reduktion der EGF-Expression in den Uterindrüsen. Dies wiederum könnte zu der verringerten Proliferation des Allantochorions bei der gestörten Trächtigkeit geführt haben. Dieses Ergebnis unterstützt weiterhin das Konzept, daß Wachstumsfaktoren eine erhebliche Rolle in der Entwicklung der equinen Plazenta spielen. Die Befunde besitzen darüber hinaus eine Bedeutung hinsichtlich der Endometrose bei tragenden Stuten. Ein charakteristisches Bild der Endometrose stellt die Reduktion oder das Fehlen von EGF innerhalb fibrotischer Drüsennester dar.

Schlüsselwörter: Pferd, Plazenta, Wachstumsfaktoren, Zellproliferation

\section{Introduction}

Development of the chorioallantoic placenta in the mare involves extensive proliferation and remodelling of both the fetal membranes and the maternal endometrium to facilitate formation the complex microcotlyledonary structure needed for materno-fetal exchange (Samuel et al., 1974). The initial stimulus to this process is believed to come from the fetal membranes, specifically the allantochorion, which begins to interdigitate with the endometrium from about day 40 after ovulation. Fetally-derived growth factors are thought to provide the initial mitogenic and morphogenic stimuli, including insulin-like growth factor II (IGF II) and hepatocyte growth factor - scatter factor (HGF-SF), the genes for which are both expressed in the highly vascularised allantoic mesenchyme within the allantochorion (Lennard et al., 1995a; Stewart et al., 1995). However, maternal factors such as transforming growth factor $\beta 1$ (TGF $\beta 1$ ) and epidermal growth factor (EGF) are also believed to be involved, particularly after the allantochorion and endometrium have made contact and begin to interdigitate. Increasing expression of TGF $\beta 1$ mRNA in the luminal epithelium of the endometrium from about day 30 may influence cell differentiation (Lennard et al., 1995b) and a marked upregulation in the 
expression of EGF in the glandular epithelium from about day 40 is believed to play an important mitogenic role in the proliferation of both fetal and maternal epithelial cells (Stewart et al., 1994; Lennard et al., 1998). The stimulus that increases the rise in TGF $\beta 1$ expression is not known but the dramatic increase in glandular EGF expression from day 40 onwards appears to be due to prolonged exposure of the tissues to progesterone (Gerstenberg et al., 1999a).

A very useful model to investigate factors controlling placentation in the mare is created by transferring donkey blastocysts (Equus asinus, $2 n=62$ ) to horse mares ( $E$. caballus, $2 n=64$ ) between days 6 and 7 after ovulation. These extraspecific pregnancies appear to develop normally for the first few weeks of gestation and some of them manage to develop an adequate placenta and proceed safely to term (Allen, 1982). However, none of them develop endometrial cups and the majority show delayed and abnormal placentation which results in fetal death and abortion between days 80 and 100 of pregnancy (Allen et al., 1987; Enders et al., 1996). Microscopic examination of biopsies of the placental interface, sampled between days 60 and 70 of gestation in these mares, shows areas of reasonable attachment and interdigitating villous formation but also large areas of poor attachment with rudimentary unattached villi. These latter regions are also usually associated with lymphocytic infiltration of the adjacent endometrium with lymphocytes (Allen et al., 1987).

To further investigate the role of growth factors in equine placentation, the present study compared the histological appearance and the cell proliferation and growth factor expression patterns in mares carrying normal ongoing intraspecific horse pregnancies with those in mares carrying failing, transferred donkey-in-horse pregnancies.

\section{Materials and methods}

\section{Animals and tissues}

Six pony - type mares of mixed breeding, aged 3-5 years, were used. Three were inseminated with extended stallion semen during oestrus and were subsequently diagnosed pregnant by ultrasonographic examination of their uteri between days 15 and 18 after ovulation. The donkey-in-horse pregnancies were created by surgically transferring a day 7 donkey blastocyst to each of the other three unmated mares, 5 or 6 days after they had ovulated (Allen, 1982); these mares had previously aborted a transferred donkey fetus and were therefore known to be „non carriers" of donkey conceptuses (Allen et al., 1987). On day 70 of gestation, 4 biopsies were collected from different areas of the placental interface in all 6 pregnancies at laparotomy performed under halothane- maintained general anaesthesia. The pieces of tissue were frozen immediately in isopentane over liquid nitrogen, stored at $-70^{\circ} \mathrm{C}$, cryosectioned at $6-7 \mu \mathrm{m}$, fixed in $4 \%$ paraformaldehyde in PBS for $5 \mathrm{~min}$., dehydrated in an ethanol series and stored at $4^{\circ} \mathrm{C}$ in $95 \%$ ethanol.

\section{In situ hybridisation}

The tissue sections were removed from the ethanol, dried at room temperature for 5-10 min and hybridised to the TGF $\beta 1$ and EGF $S^{35}$-labelled sense and antisense oligonucleotide probes as described previously by Stewart et al., (1994) and Lennard et al., (1995b). After extensive washing in 2X SSC $(300 \mathrm{mM} \mathrm{NaCl}, 30 \mathrm{mM}$ trisodium citrate, $\mathrm{pH} 7.0)$ and rinsing in $0.1 \mathrm{X}$ SSC, the sections were exposed to $X$-ray film for $1-2$ days to assess the degree of hybridisation, coated with photographic emulsion, left in a light-proof box for 2-3 weeks, developed and stained with haematoxylin and eosin (H\&E).

\section{Immunohistochemistry}

Tissue sections were rehydrated through an ethanol series, placed into PBS and then subjected to standard immunohistochemical staining using a monoclonal antibody (MIB1; Dianova, Hamburg) to the proliferation marker Ki67 as described previously by Gerstenberg et al., 1999b). This antibody was produced against a recombinant-derived fusion protein expressed from a human Ki67 cDNA clone. The exact function of Ki67 is not known but it is found exclusively in the nuclei of proliferating cells and is therefore a very useful marker of cell division.

\section{Results and discussion}

As described previously (Allen et al., 1987), the placenta in the mares carrying donkey fetuses was characterised by areas of reasonable placental development and interdigitation interspersed with other areas showing reduced, or complete absence of, interdigitation between the allantochorion and the maternal endometrium. Furthermore, in most of these non-interdigitating areas, the endometrial stroma was heavily infiltrated with large numbers of maternal lymphocytes, thereby indicating maternal immunological recognition of foreign antigens on the donkey allantochorion. However, the nature of the antigens being recognised and the reason why the cell-mediated response is so patchy, remain unanswered questions (Allen and Short 1997).

The patterns of TGF $\beta 1$ and EGF expression were very abnormal in the donkey-in-horse pregnancies, with a marked, increasing expression of TGF $\beta 1$ in the endometrial stroma and a corresponding reduction or complete absence of expression of EGF in adjacent endometrial glands. Cell proliferation rates in both the fetal and maternal epithelial layers were also drastically reduced in these areas.

Closer examination of the abnormal areas in the failing donkey-in-horse pregnancies showed that the increase in TGF $\beta 1$ expression was almost certainly due to the presence of maternal lymphocytes. Activated lymphocytes are known to express high levels of TGF $\beta 1$ and we have demonstrated previously that equine peripheral blood lymphocytes contain significant levels of TGF $\beta 1$ mRNA (Len- 
nard et al., 1995b). Since TGF $\beta 1$ is usually associated with inhibition of cell division and promotion of differentiation, rather than cell division (Bascom et al., 1989), increased levels of TGF $\beta 1$ stemming from the maternal lymphocytes could be partly responsible for the failure of placentation by acting directly on the fetal allantochorion and/or the maternal endometrium. It could also be responsible for the reduced EGF expression seen in the adjacent endometrial glands, since only those cross sections of glands that were surrounded by a "wall" of lymphocytes showed the reduction in EGF expression. However, additional factors may arise from the accumulated lymphocytes, as the glands that were not expressing EGF were very dilated and hence similar in appearance to the EGF negative endometrial glands within endometrial and compromised, dilated glands in pregnant mares suffering from chronic endometrosis (Gerstenberg et al., 1999a). For whatever reason, the glands that were surrounded by lymphocytes were virtually devoid of EGF mRNA and this, in turn, was likely to be linked to the reduction in cell proliferation rates seen in the overlying chorion and the lack of villous interdigitation between the allantochorion and the endometrium.

Evidence that endometrial EGF is involved in placentation in the mare came both from the initial observation that the dramatic increase in its expression in the endometrial glands coincides with the commencement of allantochorionic interdigitation (Stewart et al., 1994) and from a subsequent study that demonstrated the presence of EGF receptors in the equine allantochorion throughout gestation and an increase in receptor binding activity in the endometrium after interdigitation has commenced (Lennard et al., 1998). Furthermore, EGF expression was reduced in aged, pregnant mares suffering from endometrosis and showing areas of poor placentation (Gerstenberg et al., 1999a). Therefore, the findings in the present study showing similar lack of EGF expression in areas of poor villous development and interdigitation suggest a strong causal relationship. However, it remains to be demonstrated if the EGF expressed in the equine endometrium is cleaved and secreted by the glands or if it persists as a large, membrane-bound precursor molecule in the epithelial cells lining the glands. Studies are underway to resolve this question and to determine the precise role of endometrial EGF in equine placentation.

In summary, our findings revealed aberrant endometrial growth factor expression in a model of equine placental failure and they support the hypothesis that locally produced maternal growth factors play a significant role in the development of the chorioallantoic placenta in the mare.

\section{Literature}

Allen, W.R. (1982): Immunological aspects of the endometrial cup reaction and the effects of xenogeneic pregnancy in horses and donkeys. Journal of Reproduction and Fertility Suppl 31, 57-59.

Allen, W.R., Kydd, Julia H., Boyle, M.S. and Antczak, D.F. (1987): Extraspecific donkey-in-horse pregnancy as a model of early fetal death. Journal of Reproduction and Fertility. Suppl., 35, 197-209.
Allen, W.R. and Short, R.V. (1997): Interspecific and extraspecific pregnancies in equids: Anything goes. Journal of Heredity 88 , 384-392.

Bascom, C.C., Sipes, N.J., Coffey, R.J. and Moses, H.L. (1989): Regulation of epithelial cell proliferation by transforming growth factors. Journal of Cellular Biochemistry 39, 25-32.

Enders, A., Meadows, Sally, Stewart, Francesca and Allen, W.R. (1996): Failure of endometrial cup development in the donkey-inhorse model of equine abortion. Journal of Anatomy 188, 575-589.

Gerstenberg, Cornelia, Allen, W.R. and Stewart, Francesca (1999a): Factors controlling epidermal growth factor (EGF) gene expression in the endometrium of the mare. Molecular Reproduction and Development 53, 255-265.

Gerstenberg, Cornelia, Allen, W.R. and Stewart, Francesca (1999b): Cell proliferation patterns in the equine endometrium throughout the non-pregnant reproductive cycle. Journal of Reproduction and Fertility $116,167-175$

Lennard, S.N., Stewart, Francesca and Allen, W.R. (1995a): Insulinlike growth factor II expression in the fetus and placenta of the horse during the first half of gestation. Journal of Reproduction and Fertility 103, 169-179.

Lennard, S.N., Stewart, Francesca and Allen, W.R. (1995b): Transforming growth factor $\beta 1$ expression in the endometrium of the mare during placentation. Molecular Reproduction and Development 42 , 131-140.

Lennard, S.N., Gerstenberg, Cornelia, Allen, W.R. and Stewart, Francesca (1998): Expression of epidermal growth factor and its receptor in equine placental tissues. Journal of Reproduction and Fertility 112. 49-57.

Samuel, Carol, Allen, W.R. and Steven, D.H. (1974): Studies on the equine placenta. I. Development of the microcotyledons. Journal of Reproduction and Fertility, 41, 441-445

Stewart, Francesca, Lennard, S.N. and Allen, W.R. (1995): Mechanisms controlling formation of the chorionic girdle. Biology of Reproduction Monograph Series 1, 151-159.

Stewart, Francesca, Power, C.A., Lennard, S.N., Allen, W.R., Amet, L and Edwards, R.M. (1994): Identification of the horse epiderma growth factor (EGF) coding sequence and its use in monitoring EGF expression in the endometrium of the pregnant mare. Journal of Molecular Endocrinology 12, 341-350.

\section{Dr. F. Stewart}

The Babraham Institute

Babraham

Cambridge

CB2 4AT

UK

Tel: 44 (0) 1223496455

Fax: 44 (0) 1223496032

E mail: francesca.stewart@bbsrc.ac.uk 